\title{
КРЕДИТНО-МОДУЛЬНА ОРГАНІЗАЦІЯ ВИРОБНИЧОЇ ПРАКТИКИ В СИСТЕМІ ВИЩОЇ СТОМАТОЛОГІЧНОЇ ОСВІТИ
}

\author{
А. В. Самойленко, О. О. Фастовець, В. Ю. Орищенко, С. Л. Альберт
}

Д3 “Дніпропетровська медична академія МОЗ Украӥни”

\section{CREDIT-TRANSFER ORGANIZATION OF INDUSTRIAL PRACTICE IN THE SYSTEM OF HIGHER DENTAL EDUCATION}

\author{
A. V. Samoylenko, O. O. Fastovets, V. Yu. Oryshchenko, Ye. L. Albert \\ SI "Dnipropetrovsk Medical Academy of MPH of Ukraine"
}

\begin{abstract}
Стаття присвячена проблемам організації виробничої практики зі стоматологічних дисциплін у контексті кредитномодульної системи навчання. Акцентована важливість даної форми навчальної діяльності у процесі підготовки спеціалістів. Представлений досвід проведення практики на кафедрах терапевтичної та ортопедичної стоматології. Приділена увага формам забезпечення дистанційної освіти студентам-іноземцям під час проходження виїзної практики.

The article is devoted to the problems of organization of industrial practice with stomatological disciplines in the context of the credit-transfer system of education. It focuses on the importance of this form of education in the process of preparing of specialists. It is presented the experience of practice at the Department of Therapeutic and Prosthetic Dentistry. The attention is given to forms of distance education for students-foreigners during the practices in their countries.
\end{abstract}

Вступ. Попри те, що входження вищої медичної освіти в єдиний європейський простір, яке наголошується Болонською угодою, відбулося, задача адаптації задекларованих принципів до існуючих реалій та багаторічних напрацювань залишається актуальною. Як будь-яке нововведення, впровадження кредитно-модульної системи потребує диференційованого підходу до реорганізації та реструктуризації існуючої системи навчального процесу [1].

Щодо навчання студентів-стоматологів, в найбільшій мірі, вищезазначені складності стосуються виробничої практики, тому що спеціальність передбачає не тільки володіння знаннями з дисципліни, а насамперед, високоякісне виконання професійних маніпуляцій. Цей принцип закладений у державних стандартах вищої стоматологічної освіти: освітньокваліфікаційній характеристиці (ОКХ), освітньо-професійній програмі та стандартизованих способах оцінки знань та вмінь - ліцензійованому іспиті “Крок 2. Стоматологія" та практично-орієнтованому державному іспиті зі стоматології.

Одночасно впровадження кредитно-модульної організації навчального процесу передбачає акцентування самостійної роботи студента [2]. Однак надмірна акцентуація на фантомні методи не виправдовує себе належним чином, оволодіти стоматологічними маніпуляціями студент може лише на пацієнті. У свою чергу, беручи до уваги положення про діалектичний зв' язок правила єдності свідомості і діяльності, а також принципу активності особистості, вивчення спеціальності має відбуватися в умовах, наближених до професійної діяльності. Виробнича практика дозволяє закріпити практичні навички, отримані у процесі навчання, виробити здатність доприйняття самостійного рішення в питаннях діагностики і лікування, освоїти порядок оформлення медичної документації, навчитися правильно поводитися у трудовому колективі та приймати колегіальні рішення, оволодіти правилами деонтології та медичної етики. Практика є досить важливим етапом пізнавальної діяльності як елемент матеріалізованої дії, критерій істинності знань. Треба також наголосити, що підготовка студента під час проходження лікарської практики спрямована на формування мотиваційної, когнітивної та операційної складових подальшого професійного розвитку $[3,4]$.

Виходячи з усього вищесказаного, переоцінити роль якісної організації виробничої практики на стоматологічному факультеті, як можливості закріплення практичних навичок у реальних професійних умовах, не можливо. Поруч з тим, цілком зрозуміла необхідність перебудови системи їі проведення згідно 3 засадами Болонської декларації.

Основна частина. Підготовка спеціалістів медичного профілю ведеться за концепцією постійного (ㄱ А. В. Самойленко, О. О. Фастовець, В. Ю. Орищенко, Є. Л. Альберт 
інтегрованого тренінгу за трьома етапами удосконалення рівня майстерності на етапі додипломного навчання [5].

Перший етап передбачає оволодіння практичними навичками та уміннями з профільних дисциплін і тестування рівня їхнього засвоєння на практичних заняттях. Профільні клінічні кафедри для забезпечення повноцінного самостійного тренінгу практичних навичок створюють банки методичного забезпечення за рахунок обладнання фантомами, муляжами i тренажерами, що готовить студентів до наступної роботи в клініці. Важливе місцена цьому етапі підготовки спеціаліста займає надання студенту можливостей отримувати новітню науково-практичну інформацію через постійно зростаючий бібліотечний фонд, новітні періодичні видання, електронний ресурс, впровадження навчальних та контролюючих комп'ютерних програм.

Другий етап, проякий піде мова, виробнича практика, при організації якої оцінюється початковий рівень умінь та навичок, ставиться завдання їх закріплення i розвитку, а наприкінці кінцевий контроль ступеня оволодіння, який відіграє вирішальну роль для третього етапу - інтеграції знань, умінь та навичок, самостійного поглибленого обстеження та лікування хворих, та безпосередньої підготовки до державної атестації.

Згідно з новим навчальним планом виробнича лікарська практика зі стоматології проводиться на 3 курсі (4 тижні), 4 курсі (6 тижнів) та 5 курсі (3 тижні). Вимоги до практичної підготовки студентів визначені у програмах з виробничої практики та у всіх типових навчальних програмах з клінічних дисциплін, в тому числі у наскрізних програмах. За новими правилами виробнича практика має здійснюватися відповідно до вимог ОКХ.

Програмою практики передбачено засвоєння студентом певного переліку навичок, умінь, знань, яке стає можливим за рахунок надання індивідуального робочого місця, забезпечення тематичними хворими, обладнанням, інструментарієм та матеріалами. Вихідний рівень підготовки студентів дозволяє вести прийом самостійно, але за допомогою безпосереднього керівника - лікаря-спеціаліста вищої або першої категорії. Викладач-співробітник кафедри здійснює загальне керівництво, відповідає за взаємодію з органами практичної охорони здоров'я, проводить консультативно-пояснювальну роботу серед лікарів-кураторів і студентів, здійснює контроль та підбиття підсумків.

Стосовно методологічного обгрунтування виробничої практики зі спеціальності, нами означено три основні напрямки навчання: по-перше, формування клінічного мислення, по-друге, відпрацювання практичних навичок, по-третє, засвоєння культури спілкування із хворим.

Виходячи з вищезазначених передумов, основний час практики (80 \%) відводиться для роботи в клініці. Найкраще виконанню завдання розвитку клінічного мислення у майбутніх лікарів відповідає клінічний розбір і оформлення історії хвороби у щоденнику. За кожним студентом закріплюється до 30 пацієнтів з різною стоматологічною патологією. Разом з лікарем-куратором студент проводить первинне обстеження, визначає попередній діагноз, розбирає можливі варіанти лікування і вибирає найбільш прийнятний.

Наступний рівень оволодіння спеціальністю відпрацювання мануальних дій, перелік яких випливає, перш за все, із професіограми лікаря-фахівця. Навчання здійснюється за переліком практичних навичок, обов' язкових до засвоєння, що переважно являють собою клінічні маніпуляції.

Особливості проходження практики з ортопедичної стоматології також потребують виділення певного часу (20\%) роботі в зуботехнічній лабораторії, коли студенти мають можливість ознайомитися 3 технологіями виготовлення протезів і самостійно виконати деякі лабораторні етапи. Слід зазначити, що чіткерозмежовування маніпуляцій, диференційований облік їх засвоєння готує студента до практично-орієнтованого держаного іспиту, в основі якого лежить саме демонстрація рівня оволодіння практичними навичками.

Нарешті, немаловажною складовою професійного навчання, якій необхідно приділяти увагу під час проходження практики, є формування людських якостей відповідно до фаху лікаря, а саме здатності контролювати себе, володіти емоціями, гальмувати свої афективні реакції, адекватно поводити себе в ситуаціях стресу. Досвід свідчить, що найбільш успішною формою виховної роботи зі студентами є співбесіди з питань лікарської етики та деонтологіі, ілюстровані конкретними клінічними прикладами.

Наприкінці, при наявності звітних документів, характеристики керівників, відбувається захист практики з оцінкою рівня оволодіння мануальними навичками. В ідеалі залік приймається біля крісла хворого, але на наш погляд, з урахуванням певної напруженості екзаменування, можливий і з використанням фантомів та наочних приладь. При багатоступеневій системі медичної освіти оцінка вказує на здатність людини до навчання на наступному етапі. Для підвищення об' єктивності ми практикуємо ви- 
користання матриці індивідуальних результатів засвоєння практичних навичок, коли кожна 3 них оцінюється окремо, а оцінка за практику є середньою.

Відкритим залишається питання про можливість проведення виробничої практики упродовж навчального року за накопичувальним принципом, що відповідає засадам кредитно-модульної системи навчання, в якості альтернативи цикловому методу. Перевагами теперішньої організації практики слід назвати можливість студентів брати участь у наданні стоматологічної допомоги хворим протягом усього циклу лікування від звернення та обстеження до встановлення діагнозу, санації та протезування хворого, а також так зване “занурення у професійне середовище”.

3 іншого боку, характер лікування стоматологічних захворювань дискретний, що не виключає можливості опрацювання практичних навичок протягом навчального року, тобто закріплення теоретичного матеріалу, відразу після оволодіння ним. До того ж, така "перманентна форма" допомагає формуванню висококваліфікованого стоматолога загальної практики, який на одному хворому послідовно здійснює весь обсяг терапевтичних, а потім протетичних заходів лікування.

Досвід європейських іамериканських медичних шкіл, де студенти багато навичок засвоюють самостійно в університетських клініках, на жаль, поки обмежена, тому що припускає, по-перше, наявність оснащених на сучасному рівні баз, а по-друге, вимагає значного збільшення кількості співробітників кафедр. Звідси виникає потреба розширення клінічної бази кафедр для забезпечення не тільки навчального процесу за розкладом, але й щоденного відпрацювання практичних навичок студентами-практикантами.

Для оптимізації навчального процесу, зворотного зв'язку зі студентами, оцінки діяльності лікарів-кураторів на різних клінічних базах, нами розроблена анонімна анкета, що містить 10 пунктів. За результатами анкетування 100 студентів, організаційно-методологічний рівень проведення виробничої практики в цілому їх задовольняє. Позитивним називають можливість ознайомлення з роботою стоматологічної поліклініки, опанування нових технологій, спілкування 3 лікарями, що практикують, тощо. Поруч 3 тим, переважна більшість респондентів $(84 \pm 3,7$ \%) вказує на проблеми з наданням індивідуального робочого місця, забезпечення хворими.

I на останнє, щодо диференційованого підходу в навчанні студентів-іноземців, серед яких спостерігається тенденція проходження виробничої практики у власній країні, щоповністю виправдано з огляду на можливість адаптації отриманих знань та вмінь і полегшення процесу становлення спеціаліста в майбутньому. Ми вважаємо вельми перспективним серед даного контингенту студентів розробку та впровадження дистанційних форм навчання. Доцільним є застосування як синхронних, педагогічних (за принципом безпосереднього активного спілкування), такі асинхронних, інформаційних технологій (створення, передача і збереження навчальних матеріалів, організація і супроводження навчального процесу дистанційного навчання за допомогою телекомунікаційного зв' язку)[6].

Зрозуміло, що навчання лікаря-стоматолога практичних навичок вимагає традиційного очного контакту, але вся теоретична підготовка та вправи у прийнятті рішень можуть проходити в дистанційній формі.

Для того щоб правильно розподілити час навчання на дистанційну і традиційну “фази”, немає необхідності в переробці навчального плану. Слід лише правильно сформувати інформаційний блок у форматі модульного робочого плану для самостійної роботи, а також мотивувати потребу до використання цього ресурсу балами, які отримує студент за індивідуальну роботу на сайті. Для засвоєння клінічних дисциплін особливе значення має забезпечення студентів якісними методичними розробками та відеоматеріалами навчально-інформаційного змісту.

Висновок. Розроблені державні стандарти вищої стоматологічної освіти рівня “спеціаліст”, відповідно до сучасних вимог, зорієнтовані не на змістовні, тимчасові й організаційні параметри навчального процесу, a, насамперед, на компетенцію, тобто готовність і здатність випускників стоматологічних факультетів вищих медичних навчальних закладів країни після одержання диплома виконувати професійну діяльність. Саме на таких методологічних принципах іпрофесійно-діяльнісному підході до цільової спрямованості навчального процесу орієнтована виробнича лікарська практика для студентів-стоматологів.Адаптація теперішньої системи організації виробничої практики в контексті кредитно-модульної системи потребує сполучення самостійної теоретичної підготовки з відпрацюванням практичних навичок під контролем викладача та лікаря-куратора. Відкритим залишається питання про можливість проходження виробничої практики протягом навчального року за накопичувальним принципом, що потребує розширення клінічної бази профільних кафедр. Вельми актуальним для оптимізації методологічного забезпечення виробничої практики є розробка та впровадження дистанційних форм навчання, особливо під час закордонного стажування студентів-іноземців. 


\section{Література}

1. О целесообразности кредитно-модульной организации учебного процесса в системе высшего стоматологического образования / Ю. В. Думанский, А. Н. Талалаенко, А. А. Удод [и др.] // Український стоматологічний альманах. -2011. - №4. - С. 110-115.

2. Удод А. А. Болонский процесс и стоматологическое образование в Украине: проблемы и перспективы / А. А. Удод, Л. И. Косарева, М. Б. Первак// Вісник стоматології. -2006. -№ 1(51). -С. 112-115.

3. Фастовець О. О. Виробнича практика з ортопедичної стоматології як етап підготовки спеціаліста / О. О. Фастовець // Материали за VI Международна научна практична конференция “Бъдещи изследвания - 2010”. Т. 9 : Педаго- гически науки. - София : “Бял ГРАД-БГ” ООДБ, 2010. - С. $14-16$.

4. Організація і методичнезабезпечення виробничої практики 3 терапевтичної стоматології в контексті кредитномодульної системи / Т. О. Петрушанко, А. К. Ніколішин, Н. М. Іленко [и др.] // Український стоматологічний альманах. -2012. -№6. - С. 118-123.

5. Болонський процес і система організації практичної підготовки студентів / Є. М. Нейко, Л. В. Глушко, М. І. Мізюк, І. П. Вакалюк // Медична освіта. - 2007. - № 2. - С. 56-58.

6. Казаков В. Н. Дистанционноеобучение в медицине / В. Н. Казаков, В. Г. Климовицкий, А. В. Владзимирский. Донецк: ООО “Норд”, 2005.-80 с. 